\title{
The Role of Trained Birth Attendants in Delivering PMTCT Services
}

\author{
Christian O. Isichei ${ }^{1}$, Arthur J. Ammann ${ }^{2}$ \\ ${ }^{1}$ Department of Chemical Pathology, Faculty of Medical Sciences, University of Jos, Jos, Nigeria \\ ${ }^{2}$ Global Strategies for HIV Prevention, California, USA
}

Email address:

Christian_isichei@yahoo.com (C. O. Isichei)

\section{To cite this article:}

Christian O. Isichei, Arthur J. Ammann. The Role of Trained Birth Attendants in Delivering PMTCT Services. American Journal of Health Research. Vol. 3, No. 4, 2015, pp. 232-238. doi: 10.11648/j.ajhr.20150304.15

\begin{abstract}
Nigeria was part of an HIV epidemic that once threatened to engulf all of West Africa. The trajectory was altered by the interventions of international donor agencies such as the US President's Emergency Plan for AIDS Relief (PEPFAR), local organizations, and other agencies who assisted in reducing the threat. Birth Attendants provide an important resource for Prevention of Mother-to-Child Transmission of HIV (PMTCT) as they are more affordable and accessible to most women living in the rural parts of poor developing countries like Nigeria. In March 2004, Faith Alive Foundation (FAF), in collaboration with Global Strategies for HIV Prevention, organized a training workshop for Traditional (trained) Birth Attendants (TBAs) providing services in Plateau State. The workshop curriculum was developed by Global Strategies for HIV Prevention and included HIV Prevention and Care, Voluntary Counseling and Testing (VCT) or HIV Counseling and Testing (HCT), safe delivery practices, and methods for sterilizing instruments. The trained TBAs were followed up by a Faith Alive project coordinator, who was responsible for providing continued oversight, record-keeping, quality assurance, and ongoing education and training. After more than 10 years of implementation and support, a program for PMTCT utilizing TBAs proved to be an important and sustainable tool for HIV Prevention. TBAs were able to provide insight into the lives of women in the community and to use their own experience to help bridge the gap between the clinical setting and the realities of culture and economics that often face women in Africa. Additionally, offering VCT to their clients and referral of HIV-positive women to Faith Alive provided another means whereby women living in remote areas were introduced to the wider healthcare network to access HIV Care and Support as well as other diseases. The role of trained traditional birth attendants should be integrated into PMTCT services in order to ensure that couples receive HCT, women recruited into PMTCT programs receive prophylaxis at the time of delivery, and opportunities are provided to access additional broad health care benefits.
\end{abstract}

Keywords: TBAs, PPTCT, PMTCT, HCT, VCT, HIV Counseling, HIV Testing, Traditional Birth Attendants

\section{Introduction}

The World Health Organization (WHO) notes that TBAs can potentially improve maternal and newborn health at community level. WHO defines TBA as "a person who assists the mother during childbirth and initially acquired her skills by delivering babies herself or through apprenticeship to other TBAs." Formative research to understand local beliefs, practices and their determinants have been identified as a major gap to developing effective perinatal and neonatal interventions in communities of developing countries. TBAs play an important role in settings where most births take place in the home. In Asia, TBAs constitute the largest single group of birth attendants
(41\% of births). In various studies in rural South Africa, including the Eastern Cape Province, 40 - 60\% home deliveries are conducted by TBAs. TBAs are integral members of their communities and provide an important window to local customs, traditions, and perceptions regarding childbirth and newborn care.

In Nigeria a Traditional Birth Attendant (TBA) is defined (based on the Traditional Health Practitioners Act) as a person who engages in traditional health practice and is registered under the Act. According to Nolte, the TBA in South Africa can be characterized as a middle-aged or elderly woman with no formal training, who acquired her or 
his skills through experience and attends to women during pregnancy, labour and the postnatal period in various ways. Practices may include advice or instructions as to what to eat and what not to eat; providing herbal remedies for pain, sickness or discomfort; abdominal massages; offering comfort to mothers and giving them a sense of security. They also assist with the delivery and advice and assist the new mother on how to care for the baby after birth.

The role of TBAs in caring for pregnant women and conducting deliveries is acknowledged, but generally they are not trained to deal with complications. A paradigm shift from the risk approach to focus on emergency obstetric care (every pregnancy carries a risk) has occurred since 1997. While most pregnancies and births are uneventful, all pregnancies are at risk. Around $15 \%$ of all pregnant women develop a potentially life-threatening complication. It is therefore essential for women to be cared for by skilled health workers if maternal mortality is to be reduced especially in a country like Nigeria with high burden of maternal and infant mortality. TBAs and village midwives have been employed in many interventions to reduce maternal and infant mortalities and improve pregnancy outcomes in developing countries, with mixed results, more recently in Nigeria through the government midwifery program.

Knowing and understanding the issues surrounding HIV/AIDS infection control can help birth attendants to protect themselves and others from acquiring HIV infection. Some studies in Africa show that TBAs have poor HIV knowledge and poor hygienic practices and may be at risk of occupationally acquired HIV infection along with that of Hepatitis. Recently it has been noted that TBAs can play a role in prevention of HIV from mother to child. Over the years, especially after the initial training at Faith Alive in 2004, most of these concepts or beliefs have revolutionized the role of TBAs as healthcare workers who are involved all categories of health care, "treatment",control ,Prevention and support as trained and retrained. Evaluation of training programs for TBAs on HIV/AIDS and safe delivery has proved very successful.

Worldwide, in 2010 approximately 287,000 women died while pregnant or giving birth and 3.1 million newborns died in the neonatal period. The highest incidence of maternal and perinatal mortality occurred around the time of birth with the majority of deaths within the first 24 hours after birth. Research shows that women giving birth without the assistance of a skilled attendant or a TBA are normally assisted by family members, neighbours, or deliver alone suggesting a need for conducting deliveries with the assistance of individuals with higher levels of training. The low access to skilled care, high risk of neonatal death, and integral role of TBAs and other non-skilled care providers in delivery and neonatal care highlight the need to explore alternative, low-cost, efficacious community-based interventions outside health facilities, especially for newborns.

The role of TBAs in improving maternal health has been heavily debated, especially in the context of a renewed focus on Millennium Development Goals (MDGs). While trained TBAs are not considered skilled birth attendants (SBAs), their potential contribution has been recognized in diagnosing labour, ensuring clean deliveries, detecting and referring maternal complications, providing hygienic cordcare, ensuring warmth of the newborn, supporting early exclusive breastfeeding, administration of post exposure prophylaxis(PEP), immunizations, nutritional advice, and providing counseling on a number of health topics including HIV. Other interventions, such as routine administration of misoprostol for the prevention of postpartum haemorrhage, while having been successfully administered by community-based auxiliary nurse midwives and by TBAs, need further research and evaluation. Due to variations in the nature, function, knowledge, and experience of TBAs in different settings, it is important to gain a more thorough understanding of the range of local practices and their prevalence that may lead to identification of behaviour-change interventions to improve neonatal health and survival. No doubt, TBAs are a force to reckon with in HIV/AIDS comprehensive services especially for Prevention of Mother to Child Transmission of HIV (PMTCT) or Prevention of Parent To Child Transmision of HIV(PPTCT). In spite of some reservations about how much responsibility TBAs should assume, given the vast shortage of trained healthcare workers in community settings, it would seem that increasing the education and training of TBAs should be expanded with subsequent evaluation of their effectiveness and providing additional education and training in areas of weakness.

\section{Main Body}

Nigeria's was part of an HIV epidemic that once threatened to engulf all of West Africa but the interventions of international donor agencies such as the US President's Emergency Program for AIDS Relief (PEPFAR) and local organizations, and other agencies assisted in reducing the threat. Adult HIV prevalence increased from $1.9 \%$ in 1991 to $5.8 \%$ in and since 2001 and then stabilized at an estimated $5 \%$ in 2003 and now 3.4\%. The HIV seroprevalence obtained from screening has been incorporated in routine antenatal care, with the currently recorded prevalence rate among pregnant women shown to be below a seroprevalence of $<4 \%$. Trained (traditional, skilled) Birth Attendants (TBAs) are more accessible and affordable to most women living in the rural parts of poor developing countries like Nigeria, and in particular, to those who benefit from services at the Faith Alive Hospital and Prevention of Mother-to-Child Transmission of HIV (PMTCT) Center. They have contributed in no small measure in decreasing the prevalence of HIV in Plateau state in particular and Nigeria in general. HIV/AIDS services were first offered at Faith Alive in 1998. PMTCT services were first rendered in 2000 with the first baby born free of HIV following the use of single dose nevirapine in 
the year 2001. When PMTCT was initially implemented it was noted that up to $50 \%$ of the women were lost to followup at the time of delivery resulting in difficulties in measuring the success of the PMTCT intervention. Faith Alive chose to follow the principle of using TBAs in PMTCT as documented in Cameroon by Bulterys and his colleagues. Bulterys suggested that with appropriate training and supervision, TBAs could serve as a useful strategy for community mobilization to ensure that prophylaxis is administered at the time of delivery and HCT effectively carried out.

In March 2004, Faith Alive Foundation, in collaboration with Global Strategies for HIV Prevention, organized a training workshop for Traditional (trained) Birth Attendants (TBAs) providing services in Plateau State. Fifty-eight TBAs of various backgrounds were trained using the common "pidgin English" as a means of communication and with occasional interpretation in Hausa. The workshop curriculum, which was developed by Professor Arthur Ammann and the Center for HIV Information at the University of California and included HIV overview/facts/myths, HIV prevention, care and support, voluntary counseling and testing (VCT), /HIV counseling and testing (HCT), safe delivery practices, and methods for sterilizing instruments/aseptic techniques. The role of TBAs in health care services in PMTCT and continued relevance/evaluation were also considered during the training. The training was presented in a week-long workshop and has continued annually with improvements in educational materials and updates in the most recent advances in HIV prevention, treatment, support and care. The first workshop concluded with certificates of completion and distribution of a "Doc in a Box" containing the tools necessary for the implementation of VCT/HCT and PMTCT. As part of the training, the TBAs were assisted in developing specific action plans (Table 1) with associated timelines to be implemented on return to their communities. The trained TBAs were followed up by a Faith Alive Project coordinator, who was responsible for providing continued oversight, record-keeping, quality assurance, and ongoing education and training. Since 2004, this has been an ongoing project/program with great successes, some challenges notwithstanding. Recent evidence suggests that Faith Alive's approach to HIV VCT/HCT and PMTCT/PPTCT has been successful. In 2014, through the AIDS Prevention Initiative in Nigeria's (APIN) PEPFAR program and between the months of June and September 2014, Faith Alive Foundation screened 4033 pregnant women mainly using TBAs. 57(1.4\%) were HIV positive in eighty three ( 83) different communities of Jos East, North and South of Plateau State with each having district heads that the team worked through along with community and religious leaders. This gives credence to the dramatic fall in HIV prevalence nationwide and in the State of Plateau from $7.7 \%$ in 2013 to the current $2.2 \%$ and HIV Prevention from Mother To Child Transmission rate at Faith Alive to current $2.1 \%$ through Early Infant Diagnosis with use of PCR in contrast to $50 \%$ ten years ago when Highly Active Antiretroviral Therapy (HAART) was not the gold standard for all pregnant women and transmission routes such as at labour/delivery and breast milk transmission were not well handled. Routine HCT during antenatal clinics have helped with early detection of HIV and treatment with HAART. The use of TBAs along with the team/family approach to care, treatment and support at Faith Alive Foundation Hospital and PMTCT Center have contributed to the many successes and novel interventions recorded in Plateau State and in Nigeria in general.

Table 1. Action Plan of TBAs as documented at FAF and carried out quarterly.

\begin{tabular}{|c|c|c|c|c|c|}
\hline Program Area & Activities & Purpose & Person /Unit Responsible & Timeframe & Means of Verification \\
\hline \multirow[t]{5}{*}{ TBA } & $\begin{array}{l}\text { Identifying and carrying out } \\
\text { advocacy visits to TBAs }\end{array}$ & $\begin{array}{l}\text { To increase awareness and } \\
\text { ensure safety practices. }\end{array}$ & $\begin{array}{l}\text { Officer In Charge of } \\
\text { community health }\end{array}$ & 3 months & $\begin{array}{l}\text { Reports/attendance list } \\
\text { and pictures }\end{array}$ \\
\hline & $\begin{array}{l}\text { Organization of regular } \\
\text { PMTCT/PPTCT, HCT, } \\
\text { Safety and infection control } \\
\text { Trainings and supervision of } \\
\text { TBA }\end{array}$ & $\begin{array}{l}\text { To build capacity for better } \\
\text { outcome by reducing infant } \\
\text { mortality rates and to } \\
\text { prevent HIV new infection }\end{array}$ & $\begin{array}{l}\text { HOD, Administration and } \\
\text { programs }\end{array}$ & 1 month & $\begin{array}{l}\text { Attendance list/Reports. } \\
\text { Infection control manual }\end{array}$ \\
\hline & $\begin{array}{l}\text { Expansion of HCT services } \\
\text { to all the TBAs }\end{array}$ & $\begin{array}{l}\text { Identification of } \mathrm{HIV}+ \\
\text { mothers and referral to } \\
\text { PMTCT/PPTCT services at } \\
\text { FAF }\end{array}$ & $\begin{array}{l}\text { Trained Mother Buddies } \\
\text { and TSS }\end{array}$ & $\begin{array}{l}\text { All year } \\
\text { round }\end{array}$ & $\begin{array}{l}\text { HCT Register/monthly } \\
\text { reports No of new sites } \\
\text { established as } \\
\text { decentralization } \\
\text { measures }\end{array}$ \\
\hline & $\begin{array}{l}\text { Organization of joint medical } \\
\text { outreach programs }\end{array}$ & Joint working teams & $\begin{array}{l}\text { One nominee from each } \\
\text { Team/Family }\end{array}$ & Quarterly & $\begin{array}{l}\text { Registers, posters for } \\
\text { such programs }\end{array}$ \\
\hline & $\begin{array}{l}\text { Education of TBAs on proper } \\
\text { documentation and Referral } \\
\text { system }\end{array}$ & $\begin{array}{l}\text { To measure impact and } \\
\text { improve quality of services } \\
\text { provided }\end{array}$ & $\begin{array}{l}\text { Monitoring and } \\
\text { Evaluation/Strategic } \\
\text { Information unit }\end{array}$ & Quarterly & $\begin{array}{l}\text { Registers/reports and use } \\
\text { of mobile phones for } \\
\text { documentations and } \\
\text { communication of results }\end{array}$ \\
\hline
\end{tabular}

The use of trained TBAs in the Faith Alive PMTCT program resulted in an increase in the percentage of women who were documented as having received antiretroviral prophylaxis especially in rural areas from approximately $50 \%$ in 2000 to more than $98 \%$ currently including the use of HAART and cotrimoxazole prophylaxis. As of today many 
trained and re-trained TBAs are actively involved in providing VCT/HCT services as noted in our statistics below-Tables 2-5 and figures 1-4. It is estimated that $98 \%$ of infants were protected from infection with HIV as a result of effectiveness of these TBAs and Treatment Support Specialists (TSS) who themselves live with the virus and are on HARRT for no less than six months .These along with FAF's committed services in six community clinics in Nigeria at Bakin-Kogi and Kafanchan both in Kaduna State, Andaha in Nassarawa State, Hwol Yarje and Fobur in Plateau State and Yola in Adamawa state which also has Faith Alive Youth clubs in schools. These along with other social amenities such as schools and portable bore hole water have been effective in health care transformations in Nigeria particularly in HIV/AIDS services.

An interesting side note is the recording of HCT results by TBAs who cannot read or write in English. A thumb print was substituted for written results with a negative HIV recorded as a single thumb print while two thumb prints signified a positive HIV result. To assure good quality control of these HIV results Project coordinator who is in charge of Faith Alive Laboratory quality control program visit sites on regular basis and also send pre-analyzed samples for reanalysis by these TBAs each quarter.

Table 2. HCT (with testing done) for the year 2013.

\begin{tabular}{llllll}
\hline & & \multicolumn{2}{l}{ Male Ages (years) } & \multicolumn{2}{l}{ Female Ages (years) } \\
\hline S/No & Months & $\mathbf{0 - 1 4}$ & $\mathbf{> 1 4}$ & & $>\mathbf{1 4}$ \\
\hline & & $\mathbf{0 - 1 4}$ & $\mathbf{1 5}$ and above & $\mathbf{0 - 1 4}$ & $\mathbf{1 5}$ and above \\
\hline 1 & January & 16 & 382 & 31 & 617 \\
2 & February & 20 & 419 & 30 & 581 \\
3 & March & 23 & 394 & 20 & 628 \\
4 & April & 32 & 323 & 74 & 455 \\
5 & May & 13 & 308 & 21 & 429 \\
6 & June & 177 & 3086 & 256 & 4214 \\
7 & July & 22 & 394 & 58 & 583 \\
8 & August & 83 & 1151 & 129 & 3572 \\
9 & September & 48 & 512 & 35 & 645 \\
10 & October & 38 & 466 & 33 & 607 \\
11 & November & 33 & 510 & 41 & 550 \\
12 & December & 255 & 1524 & 531 & 4458 \\
& Total & 760 & 9469 & 1259 & 17339 \\
\hline
\end{tabular}

Table 3. Number of HIV positive patients/clients for the year 2013.

\begin{tabular}{llllll}
\hline S/NO & Months & Male & & \multicolumn{2}{l}{ Female } \\
\hline & & $\mathbf{0 - 1 4}$ & $\mathbf{1 5}$ and above & $\mathbf{0 - 1 4}$ & $\mathbf{1 5}$ and above \\
\hline 1 & January & 2 & 30 & 8 & 97 \\
2 & February & 5 & 24 & 2 & 97 \\
3 & March & 6 & 40 & 3 & 100 \\
4 & April & 2 & 40 & 9 & 102 \\
5 & May & 1 & 29 & 5 & 94 \\
6 & June & 15 & 47 & 35 & 235 \\
7 & July & 3 & 4 & 29 & 114 \\
8 & August & 1 & 29 & 7 & 90 \\
9 & September & 3 & 31 & 5 & 131 \\
10 & October & 6 & 41 & 6 & 107 \\
11 & November & 0 & 21 & 0 & 52 \\
12 & December & 0 & 31 & 5 & 81 \\
& Total & 44 & 367 & 114 & 1300 \\
\hline
\end{tabular}

Table 4. HCT (with testing done) for the year 2014.

\begin{tabular}{llllll}
\hline S/NO & Months & Male & \multicolumn{3}{l}{ Female } \\
\hline & & $\mathbf{0 - 1 4}$ & $>\mathbf{1 4}$ & $\mathbf{0 - 1 4}$ & $>\mathbf{1 4}$ \\
\hline & & $\mathbf{0 - 1 4}$ & $\mathbf{1 5}$ and above & $\mathbf{0 - 1 4}$ & $\mathbf{1 5}$ and above \\
\hline 1 & January & 18 & 850 & 20 & 1462 \\
2 & February & 15 & 934 & 15 & 1464 \\
3 & March & 19 & 871 & 10 & 1657 \\
4 & April & 13 & 806 & 11 & 1297 \\
5 & May & 17 & 810 & 13 & 1686 \\
6 & June & 41 & 1048 & 45 & 1268 \\
7 & July & 21 & 975 & 15 & 3071 \\
8 & August & 42 & 784 & 43 & 2652 \\
9 & September & 27 & 992 & 36 & 1971 \\
10 & October & 25 & 763 & 16 & 1009 \\
11 & November & 25 & 730 & 14 & 1032 \\
12 & December & 14 & 382 & 12 & 853 \\
& Total & 277 & 9945 & 250 & 19422 \\
\hline
\end{tabular}

Table 5. Number of HIV positive patients/clients for the year 2014.

\begin{tabular}{llllll}
\hline S/NO & Months & Male & \multicolumn{3}{l}{ Female } \\
\hline & & $\mathbf{0 - 1 4}$ & $>\mathbf{1 4}$ & $\mathbf{0 - 1 4}$ & $>\mathbf{1 4}$ \\
\hline & & $\mathbf{0 - 1 4}$ & $\mathbf{1 5}$ and above & $\mathbf{0 - 1 4}$ & $\mathbf{1 5}$ and above \\
\hline 1 & January & 3 & 54 & 5 & 148 \\
2 & February & 2 & 34 & 5 & 113 \\
3 & March & 5 & 38 & 0 & 120 \\
4 & April & 0 & 48 & 1 & 127 \\
5 & May & 2 & 53 & 3 & 116 \\
6 & June & 5 & 65 & 3 & 163 \\
7 & July & 4 & 48 & 0 & 144 \\
8 & August & 3 & 42 & 7 & 116 \\
9 & September & 3 & 35 & 4 & 104 \\
10 & October & 5 & 34 & 3 & 111 \\
11 & November & 1 & 31 & 1 & 92 \\
12 & December & 3 & 14 & 0 & 73 \\
& Total & 36 & 496 & 32 & 1427 \\
\hline
\end{tabular}

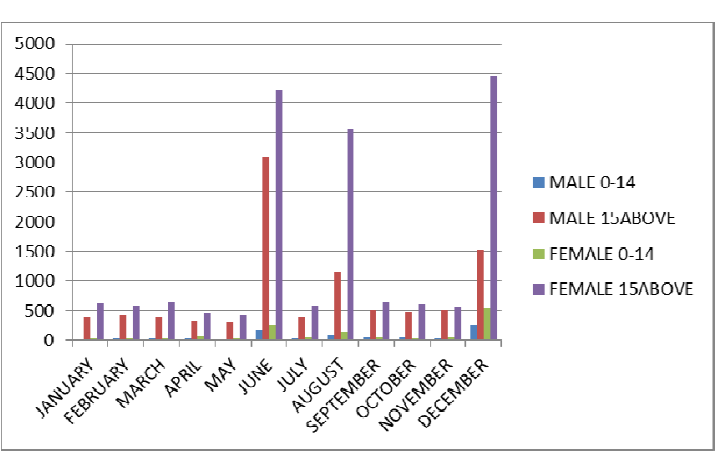

Figure 1. Bar chart showing monthly HCT (with testing done) for the year 2013.

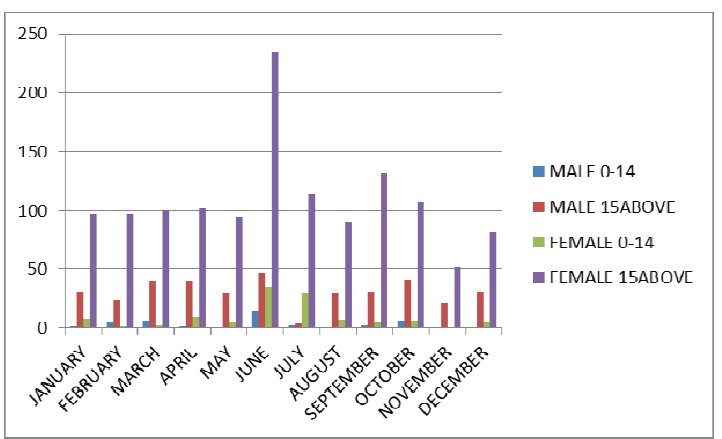

Figure 2. Bar chart showing monthly recruitment of males, females and children into FAF/PEPFAR (APIN) ART program for the year 2013. 


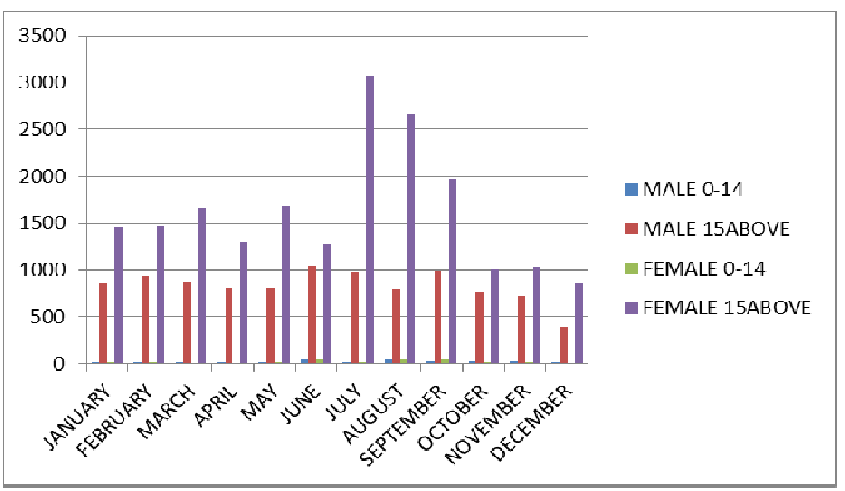

Figure 3. Bar chart showing monthly HCT (with testing done) for the year 2014

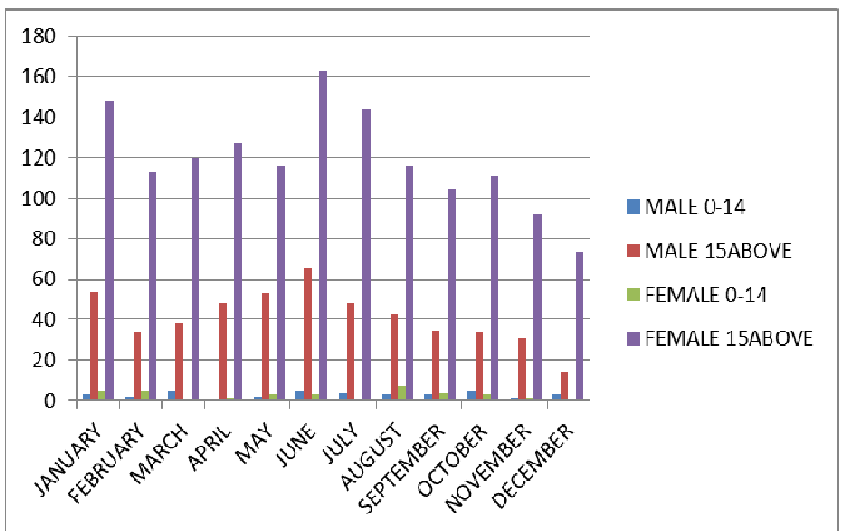

Figure 4. Bar chart showing monthly recruitment of males, females and children into FAF/PEPFAR (APIN) ART program in the year 2014.

\section{Conclusion}

Having a successful PMTCT program requires the ability to follow up women in the community settings where they feel most comfortable in delivering their infants. TBAs are able to provide insight into the lives of women in the community and to use their own experience to help bridge the gap between the clinical setting and the realities of culture and economics that often face women in Africa who are living with HIV/AIDS. There are many additional benefits including the application of training and experience in universal precautions and safe birth practices to the potential of reducing maternal sepsis and other causes of maternal mortality especially in Nigeria. Through the offering of VCT/HCT to their clients and referral of HIVpositive women to Faith Alive, this strategy provides another means whereby women living in remote areas can be introduced to a more comprehensive healthcare network to access HIV care, treatment and support as well as other health care needs.

The role of trained TBAs should be maintained in the organization of PMTCT services to ensure that all women recruited into PMTCT programs actually receive prophylaxis at the time of delivery if they are not formally enrolled into any HIV Care, treatment and support program. HIV testing during antenatal care and at labour if not previously tested should be encouraged. Faith Alive currently has a policy and an algorithm for this. It is best to view birth attendants who receive formal education and training as trained rather than traditional birth attendants in keeping with international efforts to train and retrain all healthcare workers to meet the demand for additional trained health care needs especially in rural regions of developing countries.

NOTE: First presented as abstract in 2005 as "The Role of Trained Birth Attendants in Delivering PMTCT Services". OGAC Annual Meeting at Addis Ababa, Ethiopia. 22-27 May 2005: 4-96.

\section{References}

[1] Ejele OA, Nwauche CA, Erhabor O. Seroprevalence of HIV infection among blood donors in Port Harcourt, Nigeria. Niger J Med. 2005 Jul-Sep;14(3):287-9. PubMed PMID: 16350699.

[2] Ejele OA, Nwauche CA, Erhabor O. Seroprevalence of HIV among unemployed individuals undergoing pre-employment medical examination in Port Harcourt, Nigeria. Niger J Med. 2005 Oct-Dec;14(4):419-21. PubMed PMID: 16353705.

[3] Audet CM, Hamilton E, Hughart L, Salato J. Engagement of Traditional Healers and Birth Attendants as a Controversial Proposal to Extend the HIV Health Workforce. Curr HIV/AIDS Rep. 2015 Jun;12(2):238-45. doi: 10.1007/s11904015-0258-8. PubMed PMID: 25855337; PubMed Central PMCID: PMC4430841.

[4] Rudrum S. Traditional Birth Attendants in Rural Northern Uganda: Policy, Practice, and Ethics. Health Care Women Int. 2015 Feb 26:1-20. [Epub ahead of print] PubMed PMID: 25719535 .

[5] Akalin MZ, Maine D, de Francisco A, Vaughan R. Why perinatal mortality cannot be a proxy for maternal mortality. Stud Fam Plann. 1997 Dec;28(4):330-5. PubMed PMID: 9431653.

[6] Akpala CO. An evaluation of the knowledge and practices of trained traditional birth attendants in Bodinga, Sokoto State, Nigeria. J Trop Med Hyg. 1994 Feb;97(1):46-50. PubMed PMID: 8107173.

[7] Alisjahbana A, Williams C, Dharmayanti R, Hermawan D, Kwast BE, Koblinsky M. An integrated village maternity service to improve referral patterns in a rural area in WestJava. Int J Gynaecol Obstet. 1995 Jun;48 Suppl:S83-94. PubMed PMID: 7672178.

[8] Alto WA, Albu RE, Irabo G. An alternative to unattended delivery--a training programme for village midwives in Papua New Guinea. Soc Sci Med. 1991;32(5):613-8. PubMed PMID: 2017729.

[9] Amin R, Khan AH. Characteristics of traditional midwives and their beliefs and practices in rural Bangladesh. Int $\mathrm{J}$ Gynaecol Obstet. 1989 Feb;28(2):119-25. PubMed PMID: 2563697.

[10] Bang AT, Bang RA, Sontakke PG. Management of childhood pneumonia by traditional birth attendants. The SEARCH Team. Bull World Health Organ. 1994;72(6):897-905. PubMed PMID: 7867135; PubMed Central PMCID: PMC2486734. 
[11] Bang AT, Reddy HM, Bang RA, Deshmukh MD. Why do neonates die in rural Gadchiroli, India? (Part II): estimating population attributable risks and contribution of multiple morbidities for identifying a strategy to prevent deaths. J Perinatol. 2005 Mar;25 Suppl 1:S35-43. PubMed PMID: 15791277.

[12] Bayoumi A. The training and activity of village midwives in the Sudan. Trop Doct. 1976 Jul;6(3):118-25. PubMed PMID: 785734.

[13] De Bernis L, Dumont A, Bouillin D, Gueye A, Dompnier JP, Bouvier-Colle MH. Maternal morbidity and mortality in two different populations of Senegal: a prospective study (MOMA survey). BJOG. 2000 Jan;107(1):68-74. PubMed PMID: 10645864.

[14] De Brouwere V, Tonglet R, Van Lerberghe W. Strategies for reducing maternal mortality in developing countries: what can we learn from the history of the industrialized West? Trop Med Int Health. 1998 Oct:3(10):771-82. PubMed PMID: 9809910 .

[15] Campero L, García C, Díaz C, Ortiz O, Reynoso S, Langer A. "Alone, I wouldn't have known what to do": a qualitative study on social support during labor and delivery in Mexico. Soc Sci Med. 1998 Aug;47(3):395-403. PubMed PMID: 9681909 .

[16] Castañeda Camey X, García Barrios C, Romero Guerrero X, Nuñez-Urquiza RM, Gonzalez Hernández D, Langer Glass A. Traditional birth attendants in Mexico: advantages and inadequacies of care for normal deliveries. Soc Sci Med. 1996 Jul;43(2):199-207. PubMed PMID: 8844924.

[17] Chalmers B. Traditional Indian customs surrounding birth. A review. S Afr Med J. 1993 Mar;83(3):200-3. Review. PubMed PMID: 8511689.

[18] Chowdhury M. The role of traditional birth attendants in a safe delivery programme in Bangladesh. Trop Doct. 1998 Apr;28(2):104-6. PubMed PMID: 9594684.

[19] Eades CA, Brace C, Osei L, LaGuardia KD. Traditional birth attendants and maternal mortality in Ghana. Soc Sci Med. 1993 Jun;36(11):1503-7. PubMed PMID: 8511638.

[20] Fleming JR. What in the world is being done about TBAs? An overview of international and national attitudes to traditional birth attendants. Midwifery. 1994 Sep;10(3):142-7. PubMed PMID: 7815953.

[21] Goodburn EA, Gazi R, Chowdhury M. Beliefs and practices regarding delivery and postpartum maternal morbidity in rural Bangladesh. Stud Fam Plann. 1995 Jan-Feb;26(1):22-32. PubMed PMID: 7785065.

[22] Greenwood AM, Bradley AK, Byass P, Greenwood BM, Snow RW, Bennett S, Hatib-N'Jie AB. Evaluation of a primary health care programme in The Gambia. I. The impact of trained traditional birth attendants on the outcome of pregnancy. J Trop Med Hyg. 1990 Feb;93(1):58-66. PubMed PMID: 2304134.

[23] Jordan B. Cosmopolitical obstetrics: some insights from the training of traditional midwives. Soc Sci Med. 1989;28(9):925-37; discussion 937-44. PubMed PMID: 2711228.

[24] Kamal IT. The traditional birth attendant: a reality and a challenge. Int J Gynaecol Obstet. 1998 Dec;63 Suppl 1:S4352. Review. PubMed PMID: 10075211.
[25] Koblinsky MA, Tinker A, Daly P. Programming for safe motherhood: a guide to action. Health Policy Plan. 1994 Sep;9(3):252-66. Review. PubMed PMID: 10137741.

[26] Maternal anthropometry for prediction of pregnancy outcomes: memorandum from a USAID/WHO/PAHO/MotherCare meeting. Bull World Health Organ. 1991;69(5):523-32. PubMed PMID: 1959155; PubMed Central PMCID: PMC2393257.

[27] Kwast BE. Midwives: key rural health workers in maternity care. Int J Gynaecol Obstet. 1992 Jun;38 Suppl:S9-15. PubMed PMID: 1354189.

[28] Kwast BE. Building a community-based maternity program. Int J Gynaecol Obstet. 1995 Jun;48 Suppl:S67-82. PubMed PMID: 7672176.

[29] Kwast BE. Reduction of maternal and perinatal mortality in rural and peri-urban settings: what works? Eur J Obstet Gynecol Reprod Biol. 1996 Oct;69(1):47-53. Review. PubMed PMID: 8909956.

[30] Kwast BE, Rochat RW, Kidane-Mariam W. Maternal mortality in Addis Ababa, Ethiopia. Stud Fam Plann. 1986 NovDec;17(6 Pt 1):288-301. PubMed PMID: 3798492.

[31] Lartson LI, Sodipe OA, Ebrahim GJ, Abel R. The trained traditional birth attendant: a study of her role in two cultures. J Trop Pediatr. 1987 Feb;33(1):29-34. PubMed PMID: 3573132.

[32] Leedam E. Traditional birth attendants. Int J Gynaecol Obstet. 1985 Sep;23(4):249-74. PubMed PMID: 2866113.

[33] Lefèber Y, Voorhoever H. Practices and beliefs of traditional birth attendants: lessons for obstetrics in the north? Trop Med Int Health. 1997 Dec;2(12):1175-9. Review. PubMed PMID: 9438474.

[34] Mathur HN, Damodar, Sharma PN, Jain TP. The impact of training traditional birth attendants on the utilisation of maternal health services. J Epidemiol Community Health. 1979 Jun;33(2):142-4. PubMed PMID: 490094; PubMed Central PMCID: PMC1051939.

[35] O'Rourke K. The effect of hospital staff training on management of obstetrical patients referred by traditional birth attendants. Int J Gynaecol Obstet. 1995 Jun;48 Suppl:S95-102. PubMed PMID: 7672179.

[36] Ronsmans C, Vanneste AM, Chakraborty J, van Ginneken J. Decline in maternal mortality in Matlab, Bangladesh: a cautionary tale. Lancet. 1997 Dec 20-27;350(9094):1810-4. PubMed PMID: 9428252.

[37] Ross DA. The trained traditional birth attendant and neonatal tetanus. WHO Offset Publ. 1986;(95):8-21. Review. PubMed PMID: 3529701.

[38] Sai FT, Measham DM. Safe Motherhood Initiative: getting our priorities straight. Lancet. 1992 Feb 22;339(8791):478-80. PubMed PMID: 1346829.

[39] Semali IA. Some aspects of traditional birth attendants' practice in a rural area in Tanzania. Trans R Soc Trop Med Hyg. 1992 May-Jun;86(3):330-1. PubMed PMID: 1412669.

[40] Sibley L, Armbruster D. Obstetric first aid in the community-partners in safe motherhood. A strategy for reducing maternal mortality. J Nurse Midwifery. 1997 Mar-Apr;42(2):117-21. PubMed PMID: 9107120. 
[41] Singh A. Profile of traditional birth attendants in a rural area of north India. J Nurse Midwifery. 1994 Mar-Apr;39(2):11923. PubMed PMID: 8027848.

[42] Smith JB, Coleman NA, Fortney JA, Johnson JD, Blumhagen DW, Grey TW. The impact of traditional birth attendant training on delivery complications in Ghana. Health Policy Plan. 2000 Sep;15(3):326-31. PubMed PMID: 11012408.

[43] Walraven G, Weeks A. The role of (traditional) birth attendants with midwifery skills in the reduction of maternal mortality. Trop Med Int Health. 1999 Aug;4(8):527-9. PubMed PMID: 10499075.

[44] Shabbal DM, Jamda MA, Dalhatu IT, Abdulrahman MB, Isichei C. Comparison of microalbuminuria among treatment naïve HIV sero-positive and negative adult clients in Faith Alive Foundation Hospital, Jos. Niger Med J. 2014 Nov;55(6):508-11. doi: 10.4103/0300-1652.144711. PubMed PMID: 25538372; PubMed Central PMCID: PMC4262850.

[45] Ogoina D, Pondei K, Adetunji B, Chima G, Isichei C, Gidado S. Prevalence of hepatitis $\mathrm{B}$ vaccination among health care workers in Nigeria in 2011-12. Int J Occup Environ Med. 2014 Jan;5(1):51-6. PubMed PMID: 24463801.

[46] Ogoina D, Pondei K, Adetunji B, Chima G, Isichei C, Gidado $\mathrm{S}$. Prevalence and determinants of occupational exposures to blood and body fluids among health workers in two tertiary hospitals in Nigeria. Afr J Infect Dis. 2014;8(2):50-4. PubMed PMID: 25729538; PubMed Central PMCID: PMC4325361.

[47] Anigbogu CN, Isichei CV, Ajuluchukwu JN. Blood pressure, heart rate, cardiovascular reflexes and electrocardiographic changes in some hypertensive Nigerians. Niger J Physiol Sci. 2012 Jun 7;27(1):23-7. PubMed PMID: 23235304.

[48] John C, Okolo SN, Isichei C. Nonconsensual sexual relationship and prevalence of HIV infection in adolescent in
Jos, Nigeria. Niger Med J. 2012 Oct;53(4):210-2. doi: 10.4103/0300-1652.107555. PubMed PMID: 23661880; PubMed Central PMCID: PMC3640241.

[49] Iroezindu MO, Agbaji OO, Daniyam CA, Isiguzo GC, Isichei C, Akanbi MO. Liver function test abnormalities in Nigerian patients with human immunodeficiency virus and hepatitis B virus co-infection. Int J STD AIDS. 2013 Jun;24(6):461-7. doi: 10.1177/0956462412473889. Epub 2013 Jun 24. PubMed PMID: 23970749.

[50] Durosaro O, Comfere N, Silas G, Isichei C, El-Azhary R. Dermatology and early Human Immunodeficiency Virus (HIV)/Acquired Immune Deficiency Syndrome (AIDS) recognition in Faith Alive Clinic Jos, Nigeria: a third year medical student experience. Int J Dermatol. 2009 Dec;48(12):1334-7. doi: 10.1111/j.1365-4632.2009.04196.x. PubMed PMID: 19930491.

[51] DeSilva MB, Merry SP, Fischer PR, Rohrer JE, Isichei CO, Cha SS. Youth, unemployment, and male gender predict mortality in AIDS patients started on HAARTin Nigeria. AIDS Care. 2009 Jan;21(1):70-7. doi: 10.1080/09540120802017636. PubMed PMID: 19085222; PubMed Central PMCID: PMC2849645.

[52] Lum H, Isichei C, Isichei-Wakili M, Redfield R. Expansion of HIV-1 screening and anti-retroviral treatment programs in a resource-poor setting: results from a faith-based organization in Jos, Plateau State, Nigeria. Afr Health Sci. 2007 Jun;7(2):93-100. PubMed PMID: 17594286; PubMed Central PMCID: PMC1925274.

[53] Odugbemi T, Oyewole F, Isichei CS, Onwukeme KE, Adeyemi-Doro FA. Single oral dose of azithromycin for therapy of susceptible sexually transmitted diseases: a multicenter open evaluation. West Afr J Med. 1993 JulSep;12(3):136-40. PubMed PMID: 8312208. 